\title{
7 HE WORK OF MAKING MaLTA: THE COUNCIL OF EUROPE'S ARCHAEOLOGY AND PLANNING COMMITTEE 1988-1996
}

\author{
Willem J.H. Willems \\ Leiden University, The Netherlands
}

\begin{abstract}
This article began life as a paper in the session 'Opening Doors for Archaeologists: Making Malta Work' at the 2006 EAA Annual Meeting in Kracow, Poland. It explores the background of the European Convention on the Protection of the Archaeological Heritage (Revised), also known as the Valletta Convention or the Convention of Malta. The article examines some of the major issues that were discussed and describes the drafting process of the Convention from the author's personal perspective as one of the members of the committee responsible. It concludes with a brief consideration of some subsequent developments and a plea for a more active role for the EAA at Strasbourg and Brussels.
\end{abstract}

Keywords: archaeological heritage management, Convention of Malta, Council of Europe, heritage protection, Valletta Convention

\section{INTRODUCTION}

The position of archaeology in Europe has changed fundamentally in the past two decades. We can be quite certain that the adoption, at Malta, of the European Convention on the Protection of the Archaeological Heritage (Revised) - also known as the Valletta Convention or the Convention of Malta (Council of Europe 1992) - will, in future, be considered to have been a watershed in the development of European archaeology. The Valletta Convention defines a standard for the way in which European states should manage their archaeological heritage and also provides a frame of reference in this regard for countries outside Europe. It has placed archaeology - which used to be, in the main, an academic discipline firmly in the world of spatial planning, contracting and public decision-making, unsurprisingly to the distress of some of its practitioners.

Following David Clarke, who, in the early 1970s, described the advent of archaeological theory in the previous decade as archaeology's 'loss of innocence' 
(Clarke 1973), what happened in the 1990s can well be seen as archaeology's second 'loss of innocence'. Exactly how much change has in fact occurred depends partly on the way in which the Valletta Convention has been implemented in the various countries which have embraced it. There are differences between fully or partly commercialized systems and those where archaeology has remained mostly a state monopoly. But the basic change has been the same all over Europe. In all European countries, academic practitioners are now a minority compared to those working in archaeological heritage resource management. In addition, virtually all archaeological fieldwork - also in non-commercialized systems - is now being done under contract and little remains of the once dominant systems that depended mostly on public financing through research funds. Partly as a result of this, there are widespread concerns about its relevance if not indeed its basic quality (see Willems and Van den Dries 2007). At the same time, resources for archaeology in general have risen to unprecedented levels, the in situ conservation of archaeological sites has in many cases become a realistic option, and public interest has risen enormously.

Much of this can be directly or indirectly attributed to the political success of the Valletta Convention and the effects of its implementation. Obviously, the Convention as such was not created out of thin air. This article will examine the circumstances that have preceded the signing of the Convention in 1992, the reasons for creating the new convention and the way in which this was done. ${ }^{1}$

\section{From London to Valletta}

When, on 2 October 1988, I got on the international train to Strasbourg to take part - as Dutch representative - in an expert meeting organized by the Council of Europe, I had no idea what was in store. In any case, I could not have foreseen that I was going to be involved in a process that would dominate nearly 20 years of my professional life. That meeting was the first in a series of meetings between 1988 and 1991 of the 'Select Committee of Experts on Archaeology and Planning'. The committee had been convened by the Council of Europe to prepare a revision of the so-called Convention of London of 1969, the first European Convention for the Protection of the Archaeological Heritage. It was felt that this Convention, which had not been ratified by many countries anyway, was ineffective and not suited to face the challenges of archaeology in the 1980s. My own government had never bothered to start a ratification procedure because apparently nobody thought it would add anything useful to the legal framework already in place.

The roots of this development date back to around 1970 when environmental concerns became important after publication of various reports of the Club of Rome, of which Limits to Growth (Meadows et al. 1972) was the most important. It was soon recognized that not only natural but also cultural resources are in danger and need careful management, of the type nowadays usually referred to as 'sustainable'. This became the basis for the birth of archaeological resource management or archaeological heritage management in the modern sense. In most of the western world, existing notions of historic preservation through protection of 
ancient monuments and so-called national antiquities were gradually replaced by more dynamic concepts of managing archaeological heritage resources in the framework of spatial planning systems that govern the processes of rapid change in the urban and rural landscapes. This happened first in Britain and the USA in the 1970s; it started a decade or so later in many parts of mainland Europe and has since then spread around much of the world.

In Europe the response to the threat to archaeological resources during the postwar reconstruction effort of the 1940s and 1950s had first been small-scale rescue excavations, mainly in destroyed city centres and churches, that did not differ much from the research excavations at that time. With the booming economy of the 1960s and 1970s, this strategy culminated in rescue operations at an unprecedented scale, accompanying infrastructure development all over Europe. This continued into the 1980s, with large - and typically state controlled - organizations involved in big excavation projects that dominated fieldwork. Most resources went into this type of work that was normally paid for by the government, although occasionally some funds could be obtained from the developers.

In the 1980s, however, there was a growing awareness that archaeological resources were rapidly disappearing while rescue excavation could only record a small part of the information that was irretrievably lost. The profession recognized the enormous threat to the archaeological heritage and the urgent need for a different approach, one that would require influencing the political and socioeconomic decision-making process, and would include enlisting the support of the general public. Through international conferences such as those organized by the Council of Europe in Florence in 1984 and in Nice in 1987 (Council of Europe 1987, 1989), a debate arose on these issues that hitherto had been lacking. Two ideas were central to this discussion. First, that in order to accomplish a better survival of archaeological resources, archaeology should become part of the planning process. After all, costly rescue operations were the direct result of a failure to do so. Moreover, it should become possible to actually preserve some of those resources if their importance was recognized and communicated at an early stage. Second, ideas that had been developed in the Green Movement were picked up and the 'polluter pays' principle was translated into a 'developer pays' principle; it became normal, or at least not totally outrageous, to expect developers to at least take a share in the cost of necessary archaeological work. In some parts of Europe, notably Scandinavia, such ideas already had some legal backing at the time, enabled by a favourable legal system rooted in Germanic instead of Roman law, with a different balance between private property and the rights of the King (= role of the state). For most of Europe, however, the international discussion was of vital importance in accomplishing change. Of course all governments have their own political agendas, but many processes of change, for example the introduction of environmental legislation or, more recently, the decentralization of government, and currently the legal and other measures being taken in response to the perceived risks from climate change, result from international debate and because governments influence each other. 
The spread of these new ideas about managing the historic environment was greatly accelerated by the initiative of the Council of Europe to put the issue on the political agenda and to replace the completely outdated Convention of London of 1969 by a new one that would incorporate these ideas. The London Convention had centred on issues such as illicit excavations, legal protection of sites, distribution of information, and the control and cataloguing of excavated objects. These were not considered irrelevant, but it was clear that the most serious threats to the archaeological heritage had been overlooked. The Committee of Ministers concluded, therefore, that a revision of the existing Convention would be the best way forward, ${ }^{2}$ and that is how I ended up on that train to Strasbourg in October 1988, representing the Netherlands as the new director of ROB, the Dutch State Archaeological Service.

\section{HOW THE COMMITTEE WORKED}

Figure 1 gives an overview of the initial members of the Select Committee of Experts on Archaeology and Planning. These are not all the participants, because some were replaced after a while by other colleagues, for example Professor C. Rüger was later replaced by Dr H. Cüppers from Trier. But on the whole, this was the group that did the work. There are some remarkable things about this list. First, there is nobody from Eastern Europe. This is mostly due to the fact that many states only became members after the democratic transitions in central and eastern Europe during the early 1990s. In a later stage, when the committee was continued for some years after the signing of the convention (see later section), there was some limited participation from central Europe on the committee. In addition, Bulgaria, Hungary, Poland, and Russia participated in the ministerial conference at Malta and signed the convention upon its acceptance by the Council of Ministers.

Another peculiarity of the committee is that while all members were civil servants, some were not archaeologists at all but were diplomats or lawyers. Fortunately, the majority was composed of archaeologists and specialists in heritage management. That was fortunate because we were indeed an expert committee. A similar committee, that had not long before attempted to draft a European Convention for the underwater cultural heritage, had failed. An important reason for that failure was the composition of the group - representatives sent to Strasbourg to defend national interests that had nothing to do with underwater archaeology and everything with territorial waters. There was no such thing in our group. The non-archaeologists did not on average play a major role in the committee's deliberations with the notable exception of Carsten Lund, a lawyer from Denmark with broad experience in archaeological heritage management. ${ }^{3}$

Of course there were national preoccupations, such as, for example, the issue of trafficking in illegally obtained finds. Greece, Turkey, Italy, and Cyprus were very keen on getting very strong paragraphs on this issue into the new Convention. That never happened, because the United Kingdom, Switzerland, and the Netherlands, were very much opposed. As the Dutch representative I was, however, mostly 
Dr Gustav Trotzig, Riksantivarieambetet, Sweden (CHAIR)

Oberrat dr. Hans Horcicka, Wien, Austria

M.P. Dartevelle, Brussels, Belgium

A. Daveronas, Planning Department, Nicosia, Cyprus

Dr Carsten Lund, Skov- og Naturstyrelsen, Denmark

Professor Marc Gauthier, Inspecteur Général, Paris, France

Dr Christoph Rüger, Verband der Landesarchäologen in der BRD,

Bonn, W.-Germany

Dr Charalambos Pennas, Ministry of Culture, Greece

Mme Clelia Laviosa, Ispettore Centrale, Roma, Italy

Professor Willem Willems, ROB, Amersfoort, Netherlands

Dr Fernando Real, IPPAR, Lisbon, Portugal

Dr Xavier Dupre i Raventos, Spain

Professor Charles Bonnet, Switzerland

M. Göker, Ministry of Culture, Turkey

Dr Geoffrey Wainwright, English Heritage, London, United Kingdom

Figure 1. The initial members of the Council of Europe Select Committee of Experts on Archaeology and Planning (non-archaeologists indicated in italics).

unaware of this so I had not initially made any objection, and neither had Charles Bonnet (Switzerland) if I remember correctly. I found out when the minutes of that meeting arrived and I sent them to my Ministry's cultural heritage department for comment; I was immediately instructed not to agree to any strong wording in the text.

It is of course no coincidence that the Netherlands, Switzerland and the UK are all countries with important centres for the international trade in art and antiquities, so it was their representatives that were instructed to oppose. For the same reason, none of these countries had ratified the 1970 UNESCO Convention on the Means of Prohibiting and Preventing the Illicit Import, Export and Transfer of Ownership of Cultural Property.

There were other such issues. Each of us went home after a session of the committee, collected comments from our ministries, and, in the beginning, sometimes returned for the next session with very different viewpoints. We all became more experienced and during the process learned to anticipate better what viewpoint the Ministry at home would have adopted. Most of us rapidly began to act as a group that was interested more in obtaining the best possible result for archaeology and not necessarily for our country. I remember that several times we discussed the problems in advance; we would all agree on a certain issue, but some of us would know this was unacceptable at home, so we agreed on a text that we hoped would 
survive scrutiny by lawyers and other such folk and still maintain the aspects we thought were most important.

Obviously such discussions were not in the minutes, but I recall one instance involving the issue of metal detecting. Most countries insisted that a provision would be made to ban the unlicensed use of metal detectors and we had an excellent French proposal for such an article. I recall that Geoff Wainwright (UK), who as an archaeologist could perhaps have agreed, convinced us that any such article would prevent the UK from signing the Convention, and there were one or two other members who shared this position. So we ended up not with a strong article but with a rather watered down paragraph, hidden in Article 3, that still says what the standard should be but that does not really oblige state parties to do anything. Article 3.3 reads:

[Each Party undertakes] to subject to specific prior authorisation, whenever foreseen by the domestic law of the State, the use of metal detectors and any other detection equipment or process for archaeological investigation.

Another issue, of a slightly different nature, was the definition of the archaeological heritage. In Article 1.3 it says that:

The archaeological heritage shall include structures, constructions, groups of buildings, developed sites, moveable objects, monuments of other kinds as well as their context, whether situated on land or under water.

This is not the original proposal for this paragraph, but for some northern European countries, even this was felt to be too broad because it could be interpreted to include 'built heritage', which at the time was largely separate from 'archaeological heritage' in at least three ways. First, from an academic angle because historic buildings were and often still are studied in totally different university departments from archaeology, such as art history and/or architecture. Second, in legal terms, because there are usually differences in the legal position between real estate and land - and as a result often different financial aspects such as indirect (tax reduction) and direct (grants) government funding. Third, from an organizational perspective, because the two types of heritage were mostly dealt with by separate government agencies. It is interesting to note that this last difference has now largely disappeared with mergers and other reorganizations in many European countries. The academic approach has also become more holistic.

The point was, however, that there was concern about the scope of the new Convention. Some northern countries felt that the provisions of the Convention should not apply to the built heritage because that would imply that very costly research would be required whenever historic buildings were being altered in some way. Southern countries, however, were unwilling to limit the definition of archaeological heritage because of all their extant historic buildings from Antiquity. A way out was found by stating in Article 1.2 that in order for something to be considered a part of the archaeological heritage, it must be something that is mainly ascertained through investigation of an archaeological nature. ${ }^{4}$ Whatever that was, 
was left undefined so each country could deal with this the way it wanted. It is quite interesting to see that research to reconstruct the history of existing buildings, using direct observations of the building, which was once just a branch of architecture and art history, is called 'building archaeology' in Anglo-Saxon discourse (e.g. Schuller 2002).

Of course this was not the only issue on definition. Although this is nowadays hardly even noticed any more because it is considered self-evident, we were all very proud to have succeeded in including underwater archaeological remains in the definition and to have avoided the political issues connected with them (cf. Trotzig 1993). It has since then taken a full decade before a convention on underwater heritage was finally created (by UNESCO; see e.g. O'Keefe 2002).

\section{OTHER ISSUES}

Such matters, however important they were felt to be at the time, were only side issues. The main issues were those that ended up in Articles 5, 6, and 9 of the Convention; these regulate that archaeology should become part of the planning process, that it should be financed through the budget of development schemes, and that its results should be communicated to the public. It is not my intention here to discuss the actual content of these main points of the Convention. This has been done in the explanatory report to the treaty itself, in numerous books on heritage management, and in various more specific publications over the past 15 years (e.g. Lambrick 2001; O'Keefe 1993; Trotzig 1993, 2003; Young 2001; Willems 2000).

There was of course a lot of debate involved in drafting these three central articles, but the main elements were almost beyond discussion because the need for them was felt by all and they had already been established by the recommendation of the Council of Ministers that led to the revision process. We started out with a draft that had been prepared by Professor Marc Gauthier, the French Inspecteur Général de l'Archéologie, and that made for a rapid beginning to the process. We also benefited greatly from the input from England. English Heritage had been working for some time on an improvement of national heritage management by formalizing the system pioneered in London (where development had higher profit margins), whereby developers often paid for the archaeological work that their schemes entailed, as a condition for receiving permission to develop from a planning authority. In 1990, this became the so-called Planning Policy Guidance Note 16 Archaeology and Planning (DoE 1990). The committee adopted some ideas from this guidance note and included them in the Convention.

One thing was a real discovery for me, and that was the advantage (and challenge) of having two working languages, English and French. We would regularly engage in discussions that turned out to be unnecessary because it was simply a matter of wording by the interpreters, but very often such discussions led to more precision in the words and phrases used. Sometimes, no good solution could be found. The best example of this is the useful French concept of biens culturels, a usage which simply does not have a direct English equivalent. Interpreters translated this as 'cultural properties', which is not the same and has some very different 


\section{Article 6}

Each Party undertakes:

i to arrange for public financial support for archaeological research from national, regional and local authorities in accordance with their respective competence;

ii to increase the material resources for rescue archaeology:

a by taking suitable measures to ensure that provision is made in major public or private development schemes for covering, from public sector or private sector resources, as appropriate, the total costs of any necessary related archaeological operations;

b by making provision in the budget relating to these schemes in the same way as for the impact studies necessitated by environmental and regional planning precautions, for preliminary archaeological study and prospection, for a scientific summary record as well as for the full publication and recording of the findings.

Chaque Partie s'engage:

i à prévoir un soutien financier à la recherche archéologique par les pouvoirs publics nationaux, régionaux ou locaux, en fonction de leurs compétences respectives;

ii à accroître les moyens matériels de l'archéologie préventive:

a en prenant les dispositions utiles pour que, lors de grands travaux d'aménagement publics ou privés soit prévue la prise en charge complète par des fonds provenant de manière appropriée du secteur public ou du secteur privé du coût de toute opération archéologique nécessaire liée à ces travaux;

b en faisant figurer dans le budget de ces travaux, au même titre que les études d'impact imposées par les préoccupations d'environnement et d'aménagement du territoire, les études et les prospections archéologiques préalables, les documents scientifiques de synthèse, de même que les communications et publications complètes des découvertes.

Figure 2. Article 6 of the Valletta Convention (Council of Europe 1992). There are some significant differences between the English and the French versions of the text, highlighted here by the addition of italics.

connotations (see Carman 2005). Despite all our efforts, therefore, the final text of the Convention contains some significant differences between the English and the French versions. There are, for example, two important differences in Article 6 (Fig. 2). The French text is entirely correct where it speaks of preventive archaeology, l'archéologie préventive, which is precisely what the entire Convention is about. The English text, however, speaks of 'rescue archaeology', in French that would be l'archéologie de sauvetage, which is precisely what the Convention was designed to prevent in future by integrating archaeology in the planning process! Also, when you look at the way that paragraph 6.2.b is phrased, it strikes me that the French text is considerably stronger in demanding a scientific synthesis whereas in English there is only the requirement for a summary record.

In retrospect, I have to admit I cannot recall how this came about, but it was probably because the fine-tuning was left to the legal translators of the Council of 
Europe, who are not archaeologists. And it is also true that archaeological concepts in different languages tend to have a life of their own. In any case, while French and English are the official languages of the Council of Europe and the text stands as it is, for the rest of us such differences do of course have the advantage that we can manipulate the translation into our own language somewhat. The European Union (EU) publishes its own texts in all languages, but for conventions of the Council of Europe or UNESCO it will normally be each country's own Ministry of Foreign Affairs that will produce an official translation, and this is usually done in consultation with the responsible government agency.

The translation of the text was done in the second half of 1991, when the committee had finished its work. We were all busy at home then, trying to convince our ministers to attend the planned Ministerial Conference at Malta the next year. No fewer than 20 countries actually signed the Convention in January 1992, including several from Eastern Europe that had decided to join in the process. On 1 January 2008, the number of signatures was 43 and the number of ratifications was 36, which makes this one of the really successful conventions of the Council of Europe: only six member states have not signed (Albania, Austria, Bosnia and Herzegovina, Azerbaijan, Iceland, and Montenegro) and of the signatories only seven have not yet ratified (the full list is downloadable from the website of the Council of Europe (conventions.coe 2008)).

\section{After Valletta - the work of the committee 1992-1996}

As mentioned earlier, the implementation of the Valletta Convention and its gradual incorporation into national legislation have had an important influence on archaeological heritage management in Europe. There are, however, major differences in how this works out at the national level. Some countries have signed and ratified the convention and then failed to implement it in their national legislation. The UK is the most notorious example of this (e.g. Hinton and Jennings 2007; Lambrick 2001). In federal countries, either the process never gets beyond signing, such as in Belgium, which has not ratified the convention, or the implementation may turn out to be quite different in the various states, such as in Germany (Andrikopoulou-Strack 2007; Wais and Oster 2003). Germany is also an example of an implementation practice that is widespread; ratification leads to changes in the law but the scope and impact of such changes is then established later on through litigation and the gradual establishing of jurisprudence. The Netherlands provide an example of the opposite; it has taken the Dutch an embarrassing 15 years of discussing every alternative option after signing the Convention in 1992, which led to its implementation in national law and then ratification with the Council of Europe in 2007.

There was, however, also a more immediate follow-up to the Convention because the committee that drafted the Convention was not discharged. Instead, it was continued until 1996 - when the Council of Europe got other priorities and thus 'ran out' of money for archaeology - in order to work on the so-called European Plan for Archaeology. This involved an effort to communicate the importance and relevance of archaeology to a newly reunited European audience. As 
mentioned earlier, the committee was enlarged by the addition of several countries: Bulgaria, the Holy See, Hungary, Ireland, Luxemburg, Malta, Poland, and later the Slovak Republic.

This European Plan had several activities and pilot projects connected to the standards that had been set by the Convention. All these projects were carried out by working groups of specialists from different countries. One project was to develop a 'core data standard' for archaeological sites, in cooperation with CIDOC, the documentation committee of the International Council of Museums (ICOM). This was finally published some years later (Council of Europe 1999a). A second pilot project was a comparative study of the situation of urban archaeology in the member states. This work resulted in a very useful overview with reports on 22 countries (Council of Europe 1999b; the publication is not very well known owing to the Council of Europe's apparent lack of appropriate marketing - it deserved a much wider circulation). A third activity that also resulted in a publication was a project to produce a glossary of archaeological terminology. This was intended to facilitate communication across Europe, and to provide a starting point so that the national records that were being digitized everywhere in Europe around that time, could in future be used more easily for transnational research projects. Of course this was going to require a huge effort. The basic idea was that a pilot project would be completed and, if successful, might then be continued with financial support from the EU and interested state parties. The pilot project was restricted to the Bronze Age and has resulted in a glossary (Barber and Van Regteren Altena 1999) compiled in English, French, Danish, and Dutch (and later also in Romanian). The idea was to extend it into other languages and to add the terminology for other periods, but nothing has ever become of this either for lack of finances or lack of interest.

The reason for choosing the Bronze Age for the pilot project was because of the fourth activity that the Council of Ministers decided on at Malta. This was the socalled 'Bronze Age campaign' launched by the Council of Europe as a public awareness programme to communicate the role of archaeology to the European public. As such, it was the complementary part to the other activities, which were intended primarily for professionals. Although the conferences, exhibitions, ${ }^{5}$ and other activities that were undertaken in the context of this campaign have been quite useful to archaeologists working on the Bronze Age, ${ }^{6}$ the reason for the campaign was primarily to promote archaeology and also to communicate concepts of common heritage (and its management) at a European scale. The original proposal for the campaign was made by Sweden at a symposium in Kracow in 1991, and subsequently adopted by the Council of Europe. This was the 'Conference on Security and Cooperation in Europe' symposium on cultural heritage, supported by NATO, which was apparently convinced of the importance of culture in the new Europe that was about to be created.

I recall Margaretha Biörnstad, who at that time was the state antiquary of Sweden, explaining that the Bronze Age was proposed because neither the Vikings nor the Romans seemed very suitable to promote the concept of a common European heritage. The Bronze Age was sufficiently vague and pan-European in character, at the same time having sufficient numbers of attractive artefacts which 
would be appealing to a large audience. Of course the idea also had appeal for the Eurocrats in Strasbourg, and in fact this whole campaign, also called 'The Golden Age of Europe', is an illustration of the ways in which archaeology can have a role in the political processes of unification in Europe, helping to create a European identity and consciousness. I personally did not have a problem with this and I do not think anyone else did either, at the time. And I still do not think it was wrong for a vast number of archaeologists to get involved in this project. Of course there are risks with this type of moderate political use of the past. But as long as it does not involve deliberate misrepresentation of research findings, and as long as we remember that we are not dealing with 'facts' but with interpretations, and that as archaeologists we do not 'discover' the past but are always 'constructing' it, then I can accept it.

In the end, the campaign was not very well managed and in Strasbourg there were new priorities as well as some disappointment at the level of public impact, so it was terminated with a final conference in Verona, Italy, by the end of 1996. Though some activities were not completed until 1999, the (extremely lavish) meeting in Verona marked the end of that phase of direct European interest in archaeological heritage management. There has been one final, small meeting in Strasbourg in 2002, at the 10th anniversary of the Malta Convention, where I represented the European Association of Archaeologists (EAA) as President, to give the EAA view on its implementation in Europe, together with Adrian Olivier giving his view as President of the Europæ Archæologiæ Consilium (EAC). Its proceedings are no longer accessible through the Council of Europe's website, but the EAC has completed a European survey to assess the implementation of the Convention in European countries. ${ }^{7}$

The role of the Council of Europe in archaeology or archaeological heritage management is now mostly passive. In 1999 the EAA was given consultative status as a non-governmental organization (NGO) with the Council of Europe. This could have been used as a means to continue the promotion of the interests of archaeology, as it was intended and for which the EAA is the only suitable democratic organization in Europe. But the EAA has been sadly absent in Strasbourg in recent years. This is compensated to some degree by the fact that the EAC has also established a presence in Strasbourg since its inaugural meeting there in 1999 (Willems 2000). That is not surprising, because the Committee of Experts which drafted the Valletta Convention was also the genesis of the EAC through the personal links and friendships established at committee meetings (cf. Willems 2000:14). However, the mission of the EAC is not as broad as that of the EAA, being focused on archaeological heritage management, and the EAC is not a representative organization. As an association of the heads of national organizations for archaeological heritage management it cannot speak for the archaeologists of Europe. Fortunately, however, it has been quite efficient in maintaining an archaeological presence with the Council of Europe. It has been the EAC that has become involved with the next endeavour of the Council of Europe that is highly relevant for archaeology, the European Landscape Convention (see Fairclough and Rippon 2002 and in particular the foreword and the preface). 
In the long run, however, it is clear that the interests of archaeology need to be represented at the EU in Brussels, not in Strasbourg. For the moment, the Treaty on the European Union does not include culture. In fact, the field of culture is even specifically excluded from EU competence under Article 128 of that Treaty, though EU grants and legislation do have a steadily growing impact on academic archaeology as well as on the management of archaeological resources. It would be possible for the EU to accede to the Valletta Convention because Article 15 of the latter specifically includes this option. That would introduce the Convention into EU law and reinforce its position considerably, but it may be something that is rather complicated to achieve because of the aforementioned Article 128 that explicitly excludes culture from the domains where the EU may be involved. It is more likely that managing archaeological resources within the EU will become increasingly dependent on EU legislation in other fields, such as spatial planning and the environment. The nagging question then becomes: who is in Brussels to represent our interests as a discipline and as a profession? So far, neither the EAA nor EAC have succeeded in this crucial task. Admittedly, this will not be easy to accomplish because it requires a considerable investment in both time and money, but at the moment it seems as if both organizations even lack a strategy on how to get there.

\section{ACKNOWLEDGEMENTS}

I was encouraged to publish this article by several participants in the session 'Opening Doors for Archaeologists: Making Malta Work' at the 2006 EAA Annual Meeting in Kracow, Poland. I am grateful to Kenny Aitchison and Mark Spanjer for inviting me to their session and to Gustav Trotzig for useful comments on the text of the original paper.

\section{NOTES}

1. There is one other publication I am aware of that deals with some of this - a brief but useful article by Trotzig (1993), published shortly after the treaty was signed - which is in a special section on heritage management in the journal Antiquity.

2. Recommendation No. R(89)5, concerning the protection and enhancement of the archaeological heritage in the context of town and country planning operations (see Council of Europe 1992: Explanatory Report section A.b.).

3. The Australian expert in international cultural legislation Patrick O'Keefe (see O'Keefe 1993) was not a member of the committee; he was employed as a consultant by the Council of Europe's legal department and was commissioned to write the explanatory report.

4. This is stated explicitly in the Explanatory Report to the Convention.

5. Several major exhibitions were organized, culminating with 'Gods and Heroes of the Bronze Age. Europe at the Time of Ulysses' (Copenhagen, Bonn, Paris, Athens, 1998-1999). The English version of the lavish accompanying catalogue is Demakopoulou et al. (1999).

6. See the introductions to Hänsel (1998). For an overview, see European Heritage 2 'The Bronze Age - the first golden age of Europe' (Council of Europe 1994).

7. The EAC report (The Valetta Convention: 10 years on. A survey into its adoption in national heritage policies, regulations and practice) is as yet unpublished but will eventually be accessible through EAC's website at http:/ / www.e-a-c.org/ (pers.comm. A. Olivier). 


\section{REFERENCES}

ANDRIKOPOULOU-STRACK, N.-J., 2007. Archaeology and heritage management in Germany. In W.J.H. Willems and M. van den Dries (eds), Quality Management in Archaeology: 13-21. Oxford: Oxbow Books.

BARBER, M. and J.F. VAN REgTEREN AltenA, eds, 1999. European Bronze Age Monuments. A Multilingual Glossary of Archaeological Terminology. Strasbourg: Council of Europe.

CArman, J., 2005. Against Cultural Property. Archaeology, Heritage and Ownership. London: Duckworth.

CLARKE, D.L., 1973. Archaeology: the loss of innocence. Antiquity 47(185):6-18.

CONVENTIONS.COE, 2008. URL (accessed 13 April 2008): http://conventions.coe. int/Treaty/Commun/ChercheSig.asp?NT=143\&CM=8\&DF=\&CL=ENG

Council Of Europe, 1969. European Convention on the Protection of the Archaeological Heritage. Strasbourg: Council of Europe (European Treaty Series 66).

Council Of Europe, 1987. Archaeology and Planning. Report of the Florence Colloquy. Strasbourg: Council of Europe (Architectural Heritage Reports and Studies 5).

Council of Europe, 1989. Archaeology and Major Public Works. Report of the Nice Colloquy. Strasbourg: Council of Europe (Architectural Heritage Reports and Studies 12).

COUNCIL OF EuROPE, 1992. European Convention on the Protection of the Archaeological Heritage (Revised). Strasbourg: Council of Europe (European Treaty Series 143).

Council of Europe, 1994. The Bronze Age - the first golden age of Europe, European Heritage 2. Strasbourg: Council of Europe.

Council OF EUROPE, 1999a. Core Data Standard for Archaeological Sites and Monuments. Strasbourg: Council of Europe.

COUnCIL OF EUROPE, 1999b. Report on the Situation of Urban Archaeology in Europe. Strasbourg: Council of Europe.

Demakopoulou, K., C. Eluère, J. Jensen, A. Jockenhövel and J.-P. Mohen, eds, 1999. Gods and Heroes of the European Bronze Age. London: Thames \& Hudson.

DoE (Department of The Environment), 1990. Planning Policy Guidance Note 16: Archaeology and Planning. London: HMSO.

FAIRCLOUGH, G. and S. RipPON, eds, 2002. Europe's Cultural Landscape: Archaeologists and the Management of Change. Brussels: EAC Occasional Paper 2.

HÄNSEL, B., ed., 1998. Mensch und Umwelt in der Bronzezeit Europas - Man and Environment in the European Bronze Age. Kiel: Oetker-Voges.

HinTON, P. and D. JENNINGS, 2007. Quality management of archaeology in Great Britain: present practice and future challenges. In W.J.H. Willems and M. van den Dries (eds), Quality Management in Archaeology: 100-112. Oxford: Oxbow Books.

LAmbricK, G., 2001. The Valletta Convention - A UK Perspective. Archeobrief 20:10-11.

Meadows, D.H., D.L. Meadows, J. Randers and W.W. BeHERENS III, 1972. Limits to Growth: a Report for The Club of Rome's Project on the Predicament of Mankind. New York: Universe Books (A Potomac Associates Book).

O'KeEfe, P.J., 1993. The European Convention on the Protection of the Archaeological Heritage. Antiquity 67(255): 406-413.

O'KeEFE, P.J., 2002. Shipwrecked Heritage. A Commentary on the UNESCO Convention on Underwater Cultural Heritage. Leicester: Institute of Art and Law.

Schuller, M., 2002. Building Archaeology. Paris: ICOMOS (Monuments and Sites, VII).

Trotzig, G., 1993. The new European Convention on the Protection of the Archaeological heritage. Antiquity 67(255): 414-415. 
TrotziG, G., 2003. Ten years of protection of the archaeological heritage. Naturopa 99:20.

WAIS, A. and I. Oster, eds, 2003. Archäologische Denkmalpflege in Deutschland. Stuttgart: Verband der Landesarchäologen in Deutschland.

Willems, W.J.H., ed., 2000. Challenges for European Archaeology. Zoetermeer: Ministry of OCW and Europæ Archæologiæ Consilium.

WilleMs, W.J.H. and M. VAN DEN DRIES, eds, 2007. Quality Management in Archaeology. Oxford: Oxbow Books.

YounG, C., 2001. Valletta Convention. Future implications. Conservation Bulletin 41:51-54.

\section{SUBMISSION DATA}

Received 25 April 2007; accepted 9 January 2008; revised 25 January 2008

\section{BIOGRAPHICAL NOTE}

Professor Willem J.H. Willems is professor of Archaeological Resource Management and of Roman Archaeology at Leiden University in the Netherlands, as well as dean of the Faculty of Archaeology. He studied at the University of Amsterdam and the University of Michigan, Ann Arbor. His work in Roman archaeology includes numerous articles and several monographs. He has worked mainly in archaeological heritage management, as provincial archaeologist and as project manager, State Archaeologist of the Netherlands (director of the ROB), and later as Inspector General for Archaeology at the State Inspectorate for Cultural Heritage. He has also published extensively on various aspects of archaeological heritage management. He served as President of the EAA, was the founding President of the Europæ Archæologiæ Consilium (EAC) and is currently Vice-President for Europe of the ICOMOS Committee for Archaeological Heritage Management (ICAHM).

Address: Faculty of Archaeology, Leiden University, Postbus 9515, 2300 RA Leiden, The Netherlands. [email: w.j.h.willems@arch.leidenuniv.nl]

\section{Abstracts}

Traduire en acte la Convention de Malte : Comité d'Archéologie et de Planification du Conseil de 1'Europe 1988-1996

Willem J.H.Willems

Cet article se fond sur une intervention lors de la séance «Opening Doors for Archaeologists: Making Malta Work» (Ouvrir les portes aux archéologues: Traduire en acte la Convention de Malte) à l'assemblée générale annuelle 2006 de l'EAA à Cracovie (Pologne). On y analyse le contexte de la Convention européenne pour la protection du patrimoine archéologique (révisé), aussi connu sous le nom de Convention de La Vallette ou Convention de Malte. On se penche également sur quelques-uns des principaux sujets traités lors de cette séance, et le processus d'ébauche de la convention est décrit du point de vue personnel de l'auteur, membre du comité responsable. L'article conclut par une brève considération de quelques développements ultérieurs, et lance un appel à un rôle plus actif de l'EAA à Strasbourg et à Bruxelles. 
The work of making Malta: Das Komitee für Archäologie und Planung des Europarates 1988-1996

Willem J.H. Willems

Dieser Artikel beruht auf einem Vortrag, der anlässlich der Session „Opening Doors for Archaeologists: Making Malta Work" während des 12th EAA Annual Meeting 2006 in Krakau (Polen) gehalten wurde. Er untersucht den Hintergrund des „Europäisches Übereinkommens zum Schutz des archäologischen Erbes (revidierte Fassung)", das auch unter dem Namen "Valetta-Konvention" oder "Malta-Konvention" bekannt ist. Der Beitrag beschäftigt sich mit einigen der wichtigsten Themen, die diskutiert wurden, und beschreibt den Entwicklungsprozess der Konvention aus der persönlichen Sicht des Verfassers, der zu den Mitgliedern des verantwortlichen Komitees gehörte. Er schließt mit einer kurzen Zusammenfassung einiger nachfolgender Entwicklungen und tritt für eine aktivere Rolle der EAA in Straßburg und Brüssel ein.

Schlüsselbegriffe: Archäologische Denkmalpflege, Denkmalschutz, Europarat, Malta-Konvention, Valetta-Konvention 